\title{
"Murky Mercy": Michel Faber's Under the Skin and the Difficulty of Reality
}

Pre-print draft; please quote the published version (College Literature, Volume 44, Number 4, Fall 2017, pp. 591-614)

\author{
Marco Caracciolo \\ Ghent University \\ marco.caracciolo@ugent.be
}

\begin{abstract}
This article explores the complex perspectival play underlying readers' engagement with Isserley, the alien protagonist of Michel Faber's 2000 novel Under the Skin. I focus on three dimensions: first, the novel destabilizes readers' conception of the human, asking them to move between their anthropocentric assumptions and Isserley's "alien" point of view; second, it exposes the constraints that language and concepts pose on intersubjective interaction, showing any form of "mercy" to be fundamentally "murky" (to quote one of the novel's pivotal scenes); third, it calls attention to the strangeness of consciousness itself in a universe dominated by brute matter and strict physical laws. The result of these interrogations is a sophisticated novel that demonstrates literature's power to probe what Cora Diamond has called the "difficulty of reality."
\end{abstract}

\section{Introduction}

At first blush, Michel Faber's debut novel, Under the Skin, reads like a post-structuralist paradise. A female protagonist struggling with gender stereotypes and male violence in an underprivileged, rural setting? Check. A story of physical mutilation and queer body image? 
Check. A poignant critique of the mass killing of animals in the meat industry? Check. A planet collapsing under the weight of large-scale technological exploitation, here set against the pristine beauty of the Scottish Highlands? Check. There's more than enough in these pages to sate the appetite of scholars of gender studies, posthumanism, animal studies, ecocriticism. The protagonist, Isserley, is an alien surgically modified to look like a woman; her job is to pick up male hitch-hikers in the byways of Scotland, only to transport them to a remote farm where they are castrated and fattened before being slaughtered and sent, as a specialty food, to the aliens' distant homeland. It really is difficult not to read this strange, sci-fi story without detecting its political relevance. This dimension falls into a long tradition of ethical and epistemological questioning of the human in science fiction, as pointed out by Sarah Dillon $(2011,134)$ in a thoughtful close reading of Under the Skin. Likewise, literary scholars Marion Gymnich and Alexandre Segao Costa write that, in “Isserley's view of the world, human beings have the status of cattle, and the way the men caught by Isserley are treated by the aliens can be read as a cultural-critical metadiscourse [on] the way human beings treat animals in the meat industry" (2006, 85).

Under the Skin was first published in 2000 by Canongate, an independent publisher based in Edinburgh; the novel was positively reviewed in The New York Times (Alexis 2000) and The Guardian (The Guardian Online 2000), though it didn't receive the critical fanfare of Faber's best-known novel, The Crimson Petal and the White (2002). ${ }^{1}$ Interestingly, while professional reviewers found Faber's Under the Skin compelling and its protagonist fascinating in her alienness, the socio-political implications of the novel emerge less clearly in these published reviews than in the casual comments offered by reviewers on the Amazon.com website. I suggest using the latter comments as a perspective on readers' reception of this novel - a partial perspective, of course, but one that can still yield a number of interesting insights into reading strategies: "Faber states in his introduction that he wanted to write a book 
to celebrate the beauty of the planet [and] question our treatment of animals," writes a reader (Libby 2003). Another online reviewer declares: "This book is far more than a pamphlet for vegetarianism. It contains class and gender issues that make it not only a fascinating read, but also a dream to teach" (Mick "Shermanator" 2013). Another reader takes issue with the political engagement of Faber's novel: “A skillful and insightful examination of current social issues in the guise of a story about aliens farming and eating humans. Male-female gender roles and sexuality, 'speciesism,' vegetarian vs. meat-eating ideologies, and environmental depletion by bad political behavior, are all vilified in the course of the story. Of course, many people, including me, would consider this as heavy-handed political correctness transformed into art" (A Reading Shrink 2014). ${ }^{2}$

Why is this reader who denounces the novel's "political correctness" on the wrong track? Because, I will claim in this article, Under the Skin actually challenges readers to go beyond "easy" interpretations that see the novel as conveying an ideological message. My claim is that Under the Skin discourages such readings by exploring what philosopher Cora Diamond calls the "difficulty of reality" — a condition of not being able to take a clear stance vis-à-vis politically loaded questions such as those concerning animal rights or our attitude towards the environment. Only after experiencing that difficulty through the figure of the ambivalent protagonist can we fully grasp the novel's political and ethical implications, which have less to do with its pushing a specific ideological agenda than with its opening up spaces for individual reflection and collective discussion. Nancy Easterlin's remarks on ecocriticism seem especially relevant here, given the environmentalist overtones of Faber's novel: "Like other socially and politically motivated literary scholars . . . ecocritics tender evaluative judgments about texts based on the presumed degree to which the texts will raise consciousness about the environment" $(2012,95)$. On my reading, Under the Skin does not so much raise consciousness about the environment as question our own position as conscious creatures vis-à-vis the material 
environment, in a radical move that undercuts - and at the same reveals the limitations of - a certain tendency to read literature "for the message."

Joshua Landy mounts a critique of message-based readings in How to Do Things with Fictions: 'If fictions were nothing more than fancy delivery mechanisms for 'messages,' there would be little need to read them so much as once, and absolutely no reason to read them twice" (2012, 14). By contrast, Landy argues for a form of "slow" reading where we allow fictions to act on us, honing our skills and shaping our understanding of the world rather than imparting pre-packaged knowledge. For this to happen, however, we need the right kind of fictions (Landy calls them "formative fictions") and well-disposed readers. I suggest reading Under the Skin along the lines sketched by Landy: the novel manipulates readers' responses_-and particularly their engagement with the alien protagonist — so as to leave them in an ethical no man's land, where even the prima facie political "messages" (the meat industry is inhumane, etc.) become uncertain. In this process, not only are anthropocentric assumptions debunked-as in animal studies and "posthumanist" discourse — but the whole discussion on anthropocentrism is shown to be ineffectual and, ultimately, irrelevant in front of cosmic realities. ${ }^{3}$ This, I submit, is the difficulty of reality explored by Under the Skin, and this is the primary source of the "murkiness" that inspires the title of this article, emerging in one of the novel's most memorable scenes (to be analyzed in what follows).

Needless to say, not all readers will focus on this aspect of the novel. Yet I trust that some readers will recognize the ideas I will outline here; a few of the Amazon reviews of Under the Skin seem to suggest as much. I'll quote from these reviews as a heuristic device, without any claims to systematicity, and I choose Amazon over other platforms because of the wide availability and relative homogeneity of the readers' comments. ${ }^{4}$ It is my contention that online materials — such as those posted in websites and blogs - are an important tool to corroborate hypotheses about the effects on readers of particular texts or even textual strategies (see 
Robinson 2001). This method should complement the study of reviews published in more traditional venues (e.g., newspapers or literary magazines), which can offer only a partial perspective on how literature works. This is not to say that online reports are less "mediated" or less subject to constraints than published ones, of course. But their abundance- and, often, their relative unguardedness - can yield insight into aspects of the reading experience that are more difficult to glean from statements appearing in a more formal context. Taking into account these casual comments can help address the blind spots and biases that affect literary interpretation as a scholarly endeavor, and this in turn can counteract the tendency towards readings exclusively dictated by the interpreter's own "hermeneutic program," to borrow Liesbeth Korthals Altes's (2014, 96-97) phrase: the particular literary-critical trend or angle from which a text is approached (e.g., gender studies or ecocriticism). There is no such thing as an ideologically "neutral" reading strategy, and this applies to scholars and non-professional readers alike. But this doesn't mean that we shouldn't strive to level the playing field for texts to impact us beyond ideological presuppositions: looking at how texts are concretely read in non-scholarly contexts can play an important role in this project. Under the Skin makes for an ideal case study because of how it lends itself to interpretations predetermined by the critic's hermeneutic program, and yet at the same time challenges them.

The approach that I advocate is "cognitive" in the broad sense, since it looks at how literary fiction can stage philosophical questions about consciousness, knowledge, and ethics, enabling readers to experience the existential clout of such questions through bodily, emotional, and intellectual engagements. The particular experience I'll concentrate on is how Faber's novel asks us to switch from a human to a non-human (“alien") perspective without ever finding stable epistemic ground. Reading Under the Skin along these lines requires paying close attention to our attitude toward the protagonist, and particularly to the subtle balance of distance and 
closeness to the character established by Faber's novel. To the modes and temporal dynamics of readers' engagement with Isserley I turn in the next section.

\section{Perspective Reversals}

It all begins with a woman driving past a hitch-hiker again and again, in a puzzling dance that will be repeated countless times in Under the Skin: "Isserley always drove straight past a hitch-hiker when she first saw him, to give herself time to size him up. She was looking for big muscles: a hunk on legs. Puny, scrawny specimens were no use to her" $(2000,1)$. The purposefulness of the search suggests that this is no ordinary case of picking up a hitch-hiker, though why exactly Isserley needs a hitch-hiker, and why she needs one with "big muscles," remains unclear. There are strong sexual hints throughout this first chapter, and as we read these pages, eased into Isserley's thought processes by the internal focalization, we may mistake her interest in hitch-hikers for some kind of sexual fantasy. ${ }^{5}$

A tension arises between the narrative perspective, which is here keyed to Isserley's consciousness, and the reader's stance toward the narrated events: at this early stage — and given also the mysteriousness of Isserley's intentions - readers are likely to distance themselves from the protagonist's point of view. We don't know her well enough to trust her, and we have some legitimate suspicions about what she is up to, so - in doubt—we take an external, third-person stance. ${ }^{6}$ The mystery thickens when Isserley, after driving around aimlessly for a while, finally picks up a hitch-hiker and asks where he's headed: “'Just south?' she enquired as she eased the car away from the kerb, careful, as always, to flip the toggle for the indicators rather than the headlights or the windscreen wipers or the icpathua" $(2000,8)$. Appropriately enough, our first brush with Isserley's alienness is caused by an unknown, and mysterious-looking, word ("icpathua"). This is likely to estrange readers from the character even further, and it's not impossible to feel a sense of relief when the narrative perspective suddenly switches from Isserley to the hitch-hiker. Except that the hitch-hiker himself, while more transparent in his 
intentions than Isserley, is hardly a likable character. In a two-page long tirade, he only seems to think about the size of Isserley's breasts and how "[she'd] probably be a much better fuck than Janine [his girlfriend], that was for sure" $(2000,13)$.

This is the first of a long series of perspective reversals in the novel. Every time Isserley picks up a new hitch-hiker, the narrative perspective is handed over to him for about a page, giving us a glimpse into the character's mental life before returning to Isserley's consciousness. This happens in chapter 1 and again in all even-numbered chapters of the novel, sometimes more than once per chapter, and ten times across the whole novel. ${ }^{7}$ Out of ten hitch-hikers, four (chapters 1, 2, 6, 8) have brutish sexual fantasies about Isserley; three (chapters 2, 10, 12) seem puzzled by her slightly unusual appearance and wonder about her history and identity; one, a German student (chapter 2), is captivated by her beauty; two (chapters 4 and 6) have random thoughts suggestive of financial and personal hardships.

Due to their repetitive pattern these perspective shifts are difficult to miss, but they are also too fleeting — and most of the characters they focus on too disagreeable - to offer readers an alternative to Isserley's perspective, especially after her real identity comes to light. As we learn in the course of chapter 1, the "icpathua" is an anesthetic used to knock out Isserley's victims while she drives them to the farm where she lives with a small group of alien workers. The hitch-hikers are then held in an underground facility beneath the farm, fattened, slaughtered, and finally shipped as an exotic delicacy to a distant planet. Yet while this set-up may induce readers to distance themselves from Isserley, the few human minds evoked by the novel (the hitch-hikers') are too unsympathetic to provide firm foothold for readers' attitude toward the storyworld. We thus seem left with few options but to resist both Isserley's alien perspective and the picture of humanity that emerges from her victims' sex-obsessed thoughts. ${ }^{8}$

The problem, however, is that a number of strategies in Faber's novel work toward reducing the distance between readers and Isserley. Indeed, at first Isserley's "job" is likely to 
attract the audience's moral condemnation, but as readers become acquainted with the protagonist's point of view their judgment may lose edge. For one thing, it quickly becomes clear that Isserley and her alien species view humans more or less as humans view other animals. Whenever Isserley uses the word "human," she appears to refer to her own species, reserving a neologism, "vodsels," for specimens of Homo sapiens. In a close encounter with a sheep, for example, Isserley comments on the "human" appearance of the animal (the aliens, we learn, are quadrupedal and covered in fur): "It was so hard to believe the creature [the sheep] couldn't speak. It looked so much as if it should be able to. Despite its bizarre features, there was something deceptively human about it, which tempted her, not for the first time, to reach across the species divide and communicate" $(2000,63)$. Just like the passages representing the hitch-hikers' consciousness, Isserley's description of a sheep involves a complex perspectival play. In this case, however, this effect is triggered not by a change in narrative perspective (i.e., focalization) but by the multiple epistemic and axiological perspectives leveraged by the text. On the one hand, the sheep's physical similarity with her species leads Isserley to sympathize with the animal while seemingly ignoring the pain she causes in her human victims. On the other hand, the realization that humans routinely subject non-human animals to comparable suffering may temper our indignation at Isserley: after all, what the aliens are doing is not unlike our own raising non-human animals to fulfill our nutritional needs. The non-human animal thus stands between two divergent conceptions of the human (ours and Isserley's), potentially revealing the limitations of both.

Another reason why it becomes difficult to condemn Isserley's perspective wholesale is that she appears to be no less a victim of the aliens' industry than the hitch-hikers - though in a less literal sense. Isserley, we discover, was surgically modified to resemble a vodsel, and suffers from chronic pain due to the operations she underwent. Further, such bodily changes appear permanent, condemning her to living a castaway life on an alien planet, surrounded by 
leering vodsels and alien workers who ignore her because of her "non-human" (i.e., vodsellike) appearance. The novel's sustained internal focalization makes Isserley's existential predicament more palpable and, to some extent, shareable: as they engage with her, readers may be tempted to abandon their initial distrust and even develop a form of intimacy or "closeness" to her. ${ }^{9}$ Isserley's feelings of alienation from her life and resentment at her corporate employers are, after all, quite familiar. A few online reviewers of Faber's novel comment on this temporal progression in their responses to the character; consider, for instance, the following statement: “The main character, Isserley, at first seems somewhat strange, but it's only as the tale progresses that you learn just how very strange she is, and how her circumstances are perhaps even stranger. And yet, by the end, she becomes very real. This personality, who at the beginning seemed so distant, and then so impossibly different, becomes someone I can understand easily. Her motivations, her feelings, her pain . . . it all comes into clear focus" (Stoehr 2003).

Isserley's "strangeness" reflects the perspectival work we have to carry out in order to connect with her existential predicament, coming to see our own world from the point of view of a being for whom humans are only "vodsels." This leads to some of the most intensely defamiliarizing episodes of the novel. In a passage, for instance, Isserley flips through TV channels, and we may feel a shiver of astonishment as Isserley's uncomprehending gaze magnifies - and perhaps reveals - the absurdity of TV entertainment (Faber 2000, 144-145). Likewise, the sudden shifts in focalization that occur when Isserley picks up the hitch-hikers are more than a narrative device: they can be taken as a correlative of the perspective reversal the novel encourages at the interpretive level, by inviting us to temporarily share Isserley's evaluations of - and assumptions about—vodsel life. 21 Amazon reviewers comment on this aspect of Under the Skin; here are two examples: "more than anything, the book reveals our own assumptions and prejudices by taking them and flipping them on their head" (Stoehr 2003); 
"by the time you have an idea of what's going on you've been slipped oh-so-silently into a perception of the world that is different than your own" (Trotter 2005). Such perspective reversals appear to be channeled through readers' engagement with the character, and specifically through a trajectory of increasing empathetic "closeness" between the audience and Isserley, which can lead them to temporarily bracket their own anthropocentric perspective (and their condemnation of Isserley's actions).

At the same time, however, it is difficult to get rid of the sense of moral and physical disgust at the vodsels' treatment in the underground alien facility. The novel describes the prisoners' bodies as grotesquely disfigured and deformed, dwelling on their gradual loss of personal identity, their becoming shapeless lumps of flesh ripe for slaughter:

The few remaining [vodsels] were huddled together in a mound of fast-panting flesh, the divisions between one muscle-bound body and the next difficult to distinguish, the limbs confused. Hands and feet spasmed at random, as if a coordinated response was struggling vainly to emerge from a befuddled collective organism. Their fat little heads were identical, swaying in a cluster like polyps of an anemone, blinking stupidly in the sudden light. $(2000,169)$

Descriptions like this, offered at strategic intervals in chapters 5 and 8, are likely to elicit a strong reaction in the audience: as often in the grotesque mode of literary representation, they combine fear and physical disgust at bodily deformation with moral disgust at those who inflicted such horror on human beings. ${ }^{10}$ These passages thus work as a reminder that, despite the audience's possible empathetic connection with Isserley, she is partly responsible for these atrocities. This realization is likely to complicate our engagement with the character, counterbalancing the sense of intimacy created by the internal focalization. Readers' experience of the novel can thus take on a paradoxical quality: on the one hand, we feel for Isserley's 
predicament and we grasp the analogy between the aliens' treatment of the vodsels and our own treatment of non-human animals; on the other hand, we find the thought of humans fattened for alien consumption unbearable. While the latter judgment depends on low-level emotional responses to deformed bodies, the analogy between vodsels and non-human animals builds on a more sophisticated form of axiological perspective-taking, whereby we distance ourselves from anthropocentric presuppositions. Such mental states may create a tension, or a paradox, in readers' experience, where some readers may find themselves siding with Isserley despite feeling disgust at the hitch-hikers' death, or (conversely) condemning the aliens despite their sense of intimacy with one of them, Isserley.

\section{Intersubjectivity, Language, and the Difficulty of Reality}

One way to resolve the tension between the reader's and the protagonist's perspective is to construe Under the Skin as an animal rights manifesto in disguise. By involving us in the horrors of turning human beings into food, Faber's novel encourages us to see the analogy between vodsels and non-human animals in the meat industry. This remains a viable interpretive option, and one that — as I argued in the introduction — seems popular among online reviewers. Yet, on a closer look, there are elements in the novel that make this reading less convincing, calling for a more radical, and possibly more pessimistic, interpretation. Take the pain caused by Isserley's bodily modifications. Throughout the novel, we are exposed to excruciating descriptions of her physical states, and particularly of the chronic backache she has as a result of having to adopt a vertical, bipedal posture: at the beginning of chapter 3 , for instance, we read that Isserley's “contorted back muscles [kept] her hostage in her bed with the threat of needle-sharp pains" $(2000,49)$. We could expect Isserley's own suffering to help her feel sympathy toward the hitch-hikers, but this never seems to happen. Even in front of the most likable vodsels she finds on her way (for example, the German student of chapter 2), Isserley remains indifferent and unfeeling. This becomes more noticeable if we consider the apparent 
subtlety of the character's understanding of psychological phenomena, as evidenced by the many introspective passages in which she dissects her own mental life. What is it that prevents Isserley from giving human mental life its due? The problem, I will argue in this section, has to do with the "mutual unintelligibility" of language and concepts across the human/alien (or, for Isserley, vodsel/human) divide. In short, by staging a failure in the empathetic capacities of the protagonist, Under the Skin explores the limitations of intersubjective-and interspeciescommunication. The ideological "message" of the novel is thus complicated by a pessimistic stance toward the possibility of bridging the gap between self and other, especially when the "other" does not share an evolutionary history with us.

To some extent, this pessimism is already implicit in Isserley's encounter with the sheep. Prompted by the resemblance between the animal and Isserley's alien species, the character tries to 'reach across the species divide and communicate. 'Hello,' she said. 'Ahl,' she said. 'Wiin,' she said. These three greetings, which had no effect on the sheep except to make it scramble away, exhausted all the languages Isserley knew. She wasn't exactly a linguist, admittedly" (2000, 63). Isserley's failed attempt at communicating with the animal is presented as a shortcoming in her linguistic resources. This breakdown of language when faced with radical forms of otherness is further explored - and taken to a higher level of emotional tension-in one of the most memorable episodes of the novel, in chapter 8 .

Life at Isserley's farm is upset by a surprise visit of Amlis Vess, the son of Isserley's powerful employer. Amlis is portrayed as an eccentric, idealistic young man who thinks farming and slaughtering vodsels are ethically unacceptable. Despite resenting Amlis for his privileged upbringing and quasi-celebrity status, Isserley has to accompany him in a visit to the vodsels' cages in the underground facility. Suddenly, one of the vodsels (who have had their tongue cut off) picks up a stick and starts scribbling something in the dust: 
"No-one told me they had a language," marvelled Amlis . . . "My father always describes them as vegetables on legs." "It depends on what you classify as language, I guess," said Isserley dismissively. The vodsels had slumped behind his handiwork, head bowed in submission, eyes wet and gleaming. "But what does it mean?" persisted Amlis. Isserley considered the message, which was M E R C Y. It was a word she'd rarely encountered in her reading, and never on television. For an instant she racked her brains for a translation, then realized that, by sheer chance, the word was untranslatable into her own tongue; it was a concept that just didn't exist. ... She considered trying to pronounce the strange word with a contortion of her lips and a frown on her brow, as if she were being asked to reproduce a chicken's cackle or a cow's moo. Then, if Amlis asked her what it meant, she could honestly say that there was no word for it in the language of human beings. She opened her lips to speak, but realized just in time that this would be a very stupid mistake. For her to speak the word at all dignified it with the status of being a word in the first place; Amlis would no doubt go into ecstasy over the vodsels' ability to link a pattern of scrawled symbols with a specific sound, however guttural and unintelligible. At a stroke, she would be dignifying the vodsels, in his eyes, with both writing and speech. $(2000,171-172)$

Isserley's relativistic comment ("It depends on what you classify as language") serves to shrug off the word scribbled by the vodsel as an unintelligible sound, not unlike a "chicken's cackle or a cow's moo." This comparison reinforces the parallel between vodsels and nonhuman animals established over the previous chapters, implying that-just as we know the vodsel's word to be a meaningful linguistic unit in English — these animal sounds could also signify something that we humans cannot understand or conceptualize. But the word "mercy" 
takes on special significance in this pragmatic context; it attempts to open a channel of interspecies communication, involving not just the transfer of conceptual meaning but also the sharing of a set of emotional evaluations: this gesture asks Isserley to acknowledge the reality of the vodsel's subjectivity, and in particular the reality of his suffering. How are we to interpret Isserley's failure to consider the vodsel's appeal? On the one hand, we could think that she is too alienated from her surroundings to feel for the prisoner's fate. A psychologically minded reader could argue that Isserley's deep dissatisfaction with her present condition leads her to project her anger onto the vodsels - who are innocent, perhaps, but still in some sense responsible for her being where she is. As one Amazon.com reviewer puts it: "I was expecting to see [Isserley's] transformation—-becoming sympathetic towards humans-but [it] never [happened] as she never got to transcend her own angst, too stressed out getting [vodsels] for farming" (Gonzaga 2014).

However, this psychologizing reading glosses over an important aspect of this passage. "Mercy" is here embedded in a whole pragmatic context that — to us human readers — seems perfectly transparent. It almost goes without saying that the caged vodsels should deserve pity and mercy: our emotional responses and moral condemnation are so strong that they make redundant any linguistic appeal. Unable to respond to the vodsels at this level, Isserley implicitly ascribes her indifference to a failure in concepts, and in particular to the fact that "there was no word for [mercy] in the language of human beings" (i.e., with the usual perspective reversal, aliens). Isserley's lack of empathy for the vodsel is thus linked to her insufficient linguistic, and conceptual, competence. Throughout the novel, Isserley speaks fluent English with the hitch-hikers, but this single shortcoming in her conceptual resources seems to make a profound difference in ethical terms. Should we trust Isserley on this count, or should we rather take the "linguistic explanation" for the character's lack of sympathy as a rationalization of her feelings of angst and resentment? 
Different readers may offer different perspectives on this question, but - to this reader at least - no straightforward answer seems available. The novel does linger on the pitfalls of intersubjective interaction, and frames such pitfalls as specifically linguistic in character. In chapter 2 Isserley picks up a German tourist, who comments on the difficulties of communicating with his British hosts despite his apparent proficiency in English:

“I believe I . . offended them in some way. I don't know how. I think my English is not as good as it needs to be in certain situations." "It sounds excellent to me." He sighed. "That is the problem perhaps. If it was worse, there would be an expectation of ..." He laboured silently, then let the sentence roll back down the mountain. "There would not be the automatic expectation of shared understanding." $(2000,45)$

Ultimately, isn't blaming Isserley for her blindness to the vodsels' suffering also the result of an "automatic expectation of shared understanding"? We find Isserley a complex, rewarding character despite her "strangeness" because (and if) we learn to bracket this kind of expectation. But when directly faced with the vodsels' suffering, we cannot but feel for them, and are forced to acknowledge our distance from Isserley.

This problem is further explored in a climactic scene just a few pages after Isserley's encounter with the imprisoned vodsel. In one of her expeditions, Isserley offers a ride to the wrong hitch-hiker, who pulls out a knife and starts threatening her. Visibly shaken, Isserley tries to reason with the man, but he forces her to leave the main road and stop the car in the open countryside. The man then asks Isserley to perform oral sex on him at knifepoint. The scene is rendered in disturbing detail, and readers are likely to side with Isserley - and feel sympathy for her - as she submits to the man's violence. Finally, he decides to push Isserley against the car to rape her. Here the vodsel's appeal to "mercy" rushes back to Isserley's mind, with unexpected results: 
Desperately, she searched for the right word, the word that might make him stop. It was a word she knew, but had only ever seen written —in fact, only this morning, a vodsel had spelled it out. She'd never heard it spoken. "Murky," she pleaded. Both his hands were on the small of her back, the butt of the Stanley knife pressing against her spine. His penis was poking and shoving in between her thighs, straining for entry. $(2000,186)$

In her encounter with the caged vodsel, Isserley had remarked that "the word [mercy] was untranslatable into her own tongue; it was a concept that just didn't exist." She had thus fallen back on the term's alleged untranslatability to suppress the prisoner's subjectivity, hiding it from Amlis and perhaps justifying her own indifference. But here Isserley's own life is at stake, her body is being violated by a brute, and after "desperately" searching "for the right word" she does find it. The term may be untranslatable into her own, alien language, but the fact that Isserley wants to use it in this context shows that she has understood what "mercy" means, and she has done so not through concepts or dictionary shortcuts, but by experiencing a situation to which the word can be applied. One could almost say that Isserley discovers the true meaning of mercy, except — of course — that the discovery goes awry. For one thing, the brute doesn't stop. He keeps trying to have sex with Isserley, without realizing that her lack of human-like genitals makes intercourse anatomically impossible. Isserley then takes advantage of the man's confusion to plunge her long, sharp nails into his eye sockets, instantly killing him. Further, the botched sexual assault is accompanied by a less sensational—but no less significant - misuse of human language. In trying to plead for mercy, Isserley utters what sounds like an altogether different word, "murky." Surely unintended by Isserley (but intended by Faber), the resulting pun — “murky mercy"—offers a key to understanding the protagonist's two encounters with vodsels in this chapter, first as a quasi-torturer, then as a quasi-victim. In the world of Under the Skin, mercy and empathy are always precarious, biased, riddled with 
inconsistencies and misunderstandings. Concepts obfuscate understanding, words come out wrong, suffering and violence are administered in the process.

There seems to be something more structural in the "murkiness" of intersubjectivityand particularly of interspecies communication — than Isserley's alienation. Intersubjectivity is always difficult, and so is-for readers-understanding Isserley: hence the character's irreducible, and fascinating, complexity. As readers engage with Isserley they move back and forth between distance (when she inflicts violence) and closeness (when she receives it) without finding any stable ground for evaluation. One of the Amazon.com reviewers describes this feeling as follows: Faber's novel "contains elements of the surreal and the satirical, and it leaves you feeling as if the ground were giving way beneath your feet" (lb136 2002). Those who try to empathize with Isserley's plight find themselves in a gray area between condemning her (and her species), feeling for her, and acknowledging the limitations of any attempt at probing the mystery of otherness. For these readers, interpreting the novel as an animal rights manifesto is an easy way out of this "murkiness": what prevails, rather, is the sense that there are no quick fixes, that true interspecies understanding is difficult, perhaps even impossible, and languagewhile waving the illusion of understanding — more often than not gets in the way. ${ }^{11}$

By staging a series of tragic failures in empathy and intersubjective relations, Under the Skin asks us to face what Cora Diamond has called, in a powerful essay, "the difficulty of reality." 12 That phrase refers to "experiences in which we take something in reality to be resistant to our thinking it, or possibly to be painful in its inexplicability, difficult in that way, or perhaps awesome and astonishing in its inexplicability" (2003, 2-3). Building on her earlier critique of animal rights arguments in the utilitarian tradition (Diamond 1978), Diamond comments on J. M. Coetzee's lecture-novella The Lives of Animals (1999) - a text that has figured prominently in discussions on animals within philosophy and animal studies. Diamond reads that book as grappling, through the persona of a fictional writer, Elizabeth Costello, with 
the difficulty of humans' existential condition as it manifests itself in unsolvable ethical questions:

Coetzee gives us a view of a profound disturbance of soul, and puts that view into a complex context. What is done by doing so he cannot tell us, he does not know. What response we may have to the difficulties of the lectures, the difficulties of reality, is not something the lectures themselves are meant to settle. This itself expresses a mode of understanding of the kind of animal we are, and indeed of the moral life of this kind of animal. (2003, 11)

Under the Skin can be read in a similar light. Like Coetzee's Elizabeth Costello, Isserley is "a wounded woman" (Diamond 2003, 7), one whose misunderstanding of (or indifference to) the vodsels' suffering is the result of a troubled personal history as well as of more fundamental barriers between self and "alien" other. Faber's novel asks us to engage with this complex protagonist, problematizing all attempts at finding a safe position from which to judge her. It exposes - through its constant perspective reversals - the horrors of the meat industry, but it also shows empathy and "mercy" to be a long, winding road in a world where violence is always around the corner. What emerges is a deeply pessimistic perspective on the human condition, seen through the eyes — and under the skin — of a distressed alien creature. If there is an interpretive resting point in Faber's novel, intersubjectivity and the intricacies of readers' engagement with Isserley do not provide it, for such things are always "murky." Another aspect of the novel's storyworld promises to overcome these difficulties: I call it "the cosmic point of view." 


\section{The Cosmic Point of View}

Just as a reading of Under the Skin from the perspective of critical animal studies would tend to focus on the novel's apparent animal rights "message," an ecocritical interpretation may find grist for its mill in Faber's representation of the pristine landscape of the Scottish Highlands. Isserley often contrasts the beauty of the Earth with "the awful desolation, the darkness, the putrefaction" $(2000,260)$ of her own planet, ravaged by pollution and industrial exploitation (a familiar motif in dystopian science fiction; see Canavan and Stanley Robinson 2014). When Isserley takes Amlis for a drive around the farm, he is dumbstruck by the beauty of the landscape, which stretches until the edge of the sea:

At the great gate at the end of the Ablach path, not far short of the cliffs, Isserley stopped the car and turned off the engine. From here there was a clear view of the North Sea, which was silver tonight, under a sky whose eastern reaches were grey with advancing snow, while the west was still bright with the moon and stars. "Oh," said Amlis feebly. He was in shock, more or less, she could tell. He stared straight ahead at the immense, impossible waters .... After a long time, Amlis was ready to ask a question. (2000, 239)

This passage leverages an "alien" perspective to shed light on the beauty of our planeta beauty that (as the reader undoubtedly knows) is jeopardized by large-scale human exploitation, threatening to turn the Earth into a version of Isserley's devastated planet. Yet Isserley's quasi-ecstatic response to the beauty of the Earth has further implications. Empathy for other species, the novel shows, is riddled with complications and misunderstandings; but it is still empathy for another sentient being, which may reciprocate or at least respond to our feelings. Isserley's sense of communion with nature is another matter, for nature is exposed here in its brute existence - in front of which both the alien and the human (however we define 
such terms) lose their relevance. This cosmic point of view emerges from time to time in the novel; consider, for instance, Isserley's walk along a beach:

The variety of shapes, colours and textures [of the pebbles] under [Isserley's] feet was, she believed, literally infinite. It must be. Each shell, each pebble, each stone had been made what it was by aeons of submarine or subglacial massage. The indiscriminate, eternal devotion of nature to its numberless particles had an emotional importance for Isserley; it put the unfairness of human life into perspective. $(2000,61)$

Such references to non-human, cosmic phenomena complicate the environmentalist reading by showing any human impact on geological and physical realities to be ultimately negligible: after all, even an environmental disaster would only be a disaster from a human perspective, since the laws of the universe - its "indiscriminate, eternal devotion" to brute existence-would remain unperturbed. Under the Skin asks us not only to juggle our human perspective with Isserley's estranging "alienness," but attempts to resolve this tension by finding a third reference point in the indifference of an insensate cosmos. Here I would like to say a few words about the science-fictional dimension of the novel, which I've left on the sidelines so far. Cosmology has had a significant influence on science fiction as a genre (Stableford 2013). Faber clearly follows in this tradition of texts attempting to use fictional representation to explore - and possibly come to terms with — anxieties about humanity's position vis-à-vis the cosmos as a whole. Olaf Stapledon's novel Star Maker, originally published in 1937, is perhaps one of the central texts in this cosmological strand of science fiction (see, e.g., Lem 1987). The originality of Under the Skin lies in its directly conflating cosmological anxieties with the murkiest of all philosophical mysteries, the question of consciousness, or how brute matter can give rise to conscious experience. 
This thematic concern comes to the fore in the novel's conclusion. Isserley decides to leave the farm once and for all, but while on her way to an unlikely freedom she loses control of her car and collides head-on with a tree. She does not die on impact, however; realizing that her rescuers will discover who she really is, she decides to put an end to her life by triggering the car's self-destruct mechanism. As Isserley explains, the powerful explosive installed in the vehicle by alien engineers "would blow her car, herself, and a generous scoop of earth into the smallest conceivable particles. The explosion would leave a crater in the ground as big and deep as if a meteorite had fallen there" $(2000,295-296)$. This simile reflects the sudden irruption of a cosmic force - the meteorite - into Isserley's life. The protagonist's pain and existential quandaries, along with the issues in interspecies understanding explored by the novel, are thus extinguished in the blink of an eye. But the cost of this "solution" is high:

And she? Where would she go?

The atoms that had been herself would mingle with the oxygen and nitrogen in the air. Instead of ending up buried in the ground, she would become part of the sky: that was the way to look at it. Her invisible remains would combine, over time, with all the wonders under the sun. When it snowed, she would be part of it, falling softly to earth, rising up again with the snow's evaporation. When it rained, she would be there in the spectral arch that spanned from firth to ground. She would help to wreathe the fields in mists, and yet would always be transparent to the stars. She would live forever. All it took was the courage to press one button, and the faith that the connection had not been broken.

She reached forward a trembling hand.

“Here I come,” she said. (2000, 295-296) 
This final vision hints at Isserley's dissolution into more basic, elementary physical particles and forces. But despite the consolatory flavor of remarks such as "She would live forever," despite the latent panpsychism of Isserley's becoming one with the snow and the sky, the character's last thoughts anxiously inquire about the point where conscious awareness becomes unconscious matter. Literally, the sentence "The faith that the connection had not been broken" is a reference to the connection between the car's self-destruct button and the explosives stashed in its hood (Isserley hopes that the mechanism hasn't been damaged by the crash). But in this context the "connection" almost becomes a metaphor for what philosophers call "the hard problem of consciousness" (Chalmers 1995), or the relationship between conscious awareness and the physical elements that make up our brain and body. While physicalism - the idea that consciousness emerges from physical properties and processes of matter-is the dominant doctrine in today's consciousness science, philosophers and neuroscientists are still debating how exactly one should bridge this gap, or forge a connection between subjectivity and matter (see Van Gulick 2014). Isserley's “faith" is, in a sense, pinned on the possibility that this connection may be preserved after her biological death.

This, too, is an aspect of the "difficulty of reality" — a form of puzzlement, wonder, or fear which reminds us of the volatility of consciousness in front of inflexible physical laws and processes. While Isserley was, as we have seen, problematically indifferent to the vodsels' suffering, this scene calls attention to a much more radical, and disconcerting, form of indifference — namely, the insignificance of conscious awareness vis-à-vis cosmic forces. ${ }^{13}$ The car's explosion turns the "murkiness" of mercy into a flurry of insentient atoms, wiping outand only in this negative sense resolving - the tension between human and non-human perspectives that underlies Under the Skin. This conclusion thus asks us to adopt a cosmic point of view as we witness Isserley's destruction; from this position, the precariousness of human empathy and our natural habitat are trumped by the precariousness of consciousness itself. Any 
affirmative, environmentalist reading of the novel has to come to terms with the nihilistic force of this final vision.

\section{Conclusion}

I argued in this essay that Under the Skin grapples with three different, but closely intertwined, problems: first, the relativity of any conception of the "human," explored here through continuous perspective reversals in moving between readers' everyday assumptions and Isserley's "alien" point of view; second, the constraints that language and concepts pose on intersubjective interaction, turning "mercy" (and therefore sympathy, empathy, and interpersonal understanding) into an intrinsically "murky" process; third, the "strangeness" of consciousness itself in a universe dominated by insentient matter operating under strict physical laws. Read in this light, Faber's novel is an extended confrontation with the difficulty of reality, one whose power lies in the complexity and emotional resonance of the questions it raises more than in the answers it provides. "Cashing out" the novel in ideological terms is a way of sidelining these questions; only by steering clear of message-based readings can we fully face the murkiness that, at different levels, the novel is probing. One may object that this sense of murkiness, and the cosmic viewpoint that I have articulated in the previous section, are in themselves messages, but I think this would be a misrepresentation of my argument. A message is a convenient take-away statement, such as "Under the Skin tells us that we should think or do x." The murkiness, by contrast, is not convenient, and it cannot be easily encapsulated in a statement: it is an experienced sense of uneasiness that derives from a text's confrontation with issues that seem unsolvable or impenetrable — such as the relationship between conscious experience and material realities, or how we should bridge interspecies differences.

Along similar lines, Porter Abbott has made a case for a form of literary interpretation that delves into the "intentionally induced states of unknowing that are embedded within texts or, more accurately, that should be a salient part of the reader's experience of them" $(2013,20)$. 
I have argued that pre-existing biases may get in the way of this experience, and that if we value this feeling of uneasiness we should strive to distance ourselves from ideological messages and focus on the dynamic of reading a text —also by confronting other readers' statements and evaluations, as I have tried to do by discussing online reviews. The readerly dynamic of Under the Skin reflects, first and foremost, the uncertainties of our empathetic engagement with Isserley. As a reviewer of Faber's novel puts it, this text is "the moral equivalent of a trick with mirrors: you're unsure whether to root for the horribly mistreated men [the vodsels] or for Isserley and her fellow aliens" (Alexis 2000). What this shows is that empathy and sympathy for characters are not only key to readers' engagement with fiction in general (Keen 2007; Caracciolo 2014, chap. 5), but that they also play an important role in generating some of literature's most disconcerting effects.

Where does this leave us with respect to the political dimension of the novel? From a political perspective, acknowledging the difficulty of reality may seem less desirable, as an effect of literature, than picking up on the apparent animal rights or environmentalist agenda of a novel like Faber's. But this point overlooks the complexity of literature's impact on its readers. Empirical literary scholars such as Hakemulder (2000, chap. 4) have found evidence suggesting that reading literature may produce changes in beliefs and attitudes. Yet there are good reasons to think that such changes are magnified by reflection and discussion on literary texts: in Suzanne Keen's words, reading “alone (without accompanying discussion, writing, or teacherly direction) may not produce the same results as the enhanced reading that involves the subsequent discussion" $(2007,92)$. With regard to Faber's novel, an interpretation exploring the ambivalence of our engagement with Isserley — and the conceptual and ethical difficulties it poses_-is much more likely to prompt reflection and discussion than a reading falling back on straightforward ideological messages. By training readers to accept the murkiness of reality, we can more effectively turn them into critical thinkers than by spoon-feeding them with pre- 
packaged meanings. This is, on my account, the ambition of Under the Skin. It is no coincidence that some editions of the novel are accompanied by a "Reading Group Guide" asking eighteen questions about readers' experience, and touching on aspects such as Isserley's body, the reversible relationship between humans and aliens, and Isserley's understanding of human culture. This comment by an online reviewer neatly captures the difficulty of the axiological and epistemic issues raised by Under the Skin: "[The] insecurity [induced by the novel] extends even to the 18-question 'Reading Group Guide' that is appended to the book. Question 16 reads: 'Did your feelings about Isserley change as the novel went on? Can you identify what influenced the way you felt about her?' Yes and no" (lb136 2002).

\section{Notes}

${ }^{1}$ Under the Skin has enjoyed a new wave of popularity after the release of Jonathan Glazer's film adaptation in 2014. Glazer's Under the Skin is a loose adaptation that glosses over most of the novel's sci-fi backstory.

${ }^{2}$ I don't intend to drive a wedge between professional and lay readers: it is evident from these statements that at least one of the Amazon.com reviewers, Mick "Shermanator," is also a literature instructor ("a dream to teach"). Rather, I want to call attention to the different contexts in which literature can be discussed: literary scholarship, professional reviews in print media, relatively informal comments on the Web.

${ }^{3}$ For a helpful overview of critical animal studies and posthumanism, see Wolfe (2009) and Miah (2009).

${ }^{4}$ These reviews are drawn from a corpus of 209 reviews of Under the Skin available on the Amazon.com website on May 14, 2014. I explored these reviews with qualitative data analysis software ATLAS.ti 7. A more in-depth discussion and justification of this methodology can be found in Aubry (2011) and Caracciolo (2013a; 2016a).

${ }^{5}$ For example, here is a passage with strong sexual overtones: "Even while she was admiring [the hitchhiker], following the curves of his brawny shoulders or the swell of his chest under his T-shirt, savouring the thought of how superb he'd be once he was naked, she would keep one eye on the roadside, just in case an even better prospect was beckoning to her out there" (2000, 4-5).

${ }^{6}$ On the dynamics of character engagements, and particularly the interplay of distance and closeness in relating to "strange" characters, see Caracciolo (2016a). 
${ }^{7}$ Most of these focalization shifts are signaled by a typographical cue (e.g., a line break) and introduced by phrases such as "he thought" or "he wondered." Here's a complete list of the passages focalized by the hitchhikers, quoting only the first sentence. Chapter 2: "She'd better watch those [breasts], the hitcher thought. Or they'll fall into her Corn Flakes" $(2000,28)$; "Women don't dress like that, he thought, unless they want a fuck" (2000, 34); "This lift was a fortunate thing. It meant he might get to Thurso by tonight, and Orkney by tomorrow" (2000, 41). Chapter 4: "She would throw him out on his arse, for sure, the hitcher was thinking, but maybe she'd let him sleep a bitty first" $(2000,80)$. Chapter 6: "It was a pity, Dave reflected, that this Louise was only taking him as far as Pitlochry" (2000, 121); “Observing his rescuer, the hitcher was not impressed. What was this obsession women had with showing cleavage these days? he thought" (2000, 134). Chapter 8: "He was thinking, My lucky day" (2000, 177). Chapter 10: "He wondered what on earth he could say to put her at ease, and why she'd bothered to pick him up if she didn't want to talk to him" $(2000,200)$. Chapter 12: “Even as he was strapping himself in, the hitcher was thinking there was still time to change his mind" $(2000,263)$.

${ }^{8}$ On the role of so-called "imaginative resistance" in engaging with characters, see Caracciolo (2013b; 2016a, chap. 1).

${ }^{9}$ Building on the "closeness" metaphor, Jens Eder (2006) has developed a multi-dimensional account of readers' engagement with characters.

${ }^{10}$ On cognitive-level responses to grotesque representations, see Czachesz (2009).

${ }^{11}$ Sarah Dillon also sees language as central to the epistemological questions raised Faber's novel, but in a different vein: on her account, "the novel demonstrates that the division between human and nonhuman animals is indeed a question of language. . . . [It] is a division created by language" $(2011,135)$. Yet it seems to me that the novel demonstrates with equal urgency that these linguistic and conceptual barriers cannot be easily removedthat they remain in place despite our best efforts or the most transformative experiences (such as Isserley's encounter with the rapist - an episode on which Dillon also dwells). This sense of limitation is at the heart of the tragic “difficulty" that I'm exploring in this essay.

${ }^{12}$ Cf. also philosopher Stephen Mulhall's (2009) more recent engagement with the difficulty of reality in literature and philosophy.

${ }^{13} \mathrm{My}$ account of the cosmic point of view in Under the Skin is in line with Matthew Taylor's (2013) exploration of what he calls "posthuman cosmologies" in $19^{\text {th }}$ century American fiction. For more on contemporary fiction's engagement with the hard problem of consciousness and its relationship with cosmological questions, see also Caracciolo (2016b). 


\section{Works Cited}

Abbott, H. Porter. 2013. Real Mysteries: Narrative and the Unknowable. Columbus: Ohio State University Press.

Alexis, André. 2000. “Funny, You Don't Look Scottish.” The New York Times on the Web. July 30. http://www.nytimes.com/books/00/07/30/reviews/000730.30alextt.html.

A Reading Shrink. 2014. "Well-Written Horror Story.” Amazon.com Customer Reviews: Under the Skin. April 9. http://www.amazon.com/review/RPI2R400YWEGJ.

Aubry, Timothy. 2011. Reading as Therapy: What Contemporary Fiction Does for MiddleClass Americans. Iowa City: University of Iowa Press.

Canavan, Gerry, and Kim Stanley Robinson, eds. 2014. Green Planets: Ecology and Science Fiction. Middletown, CT: Wesleyan University Press.

Caracciolo, Marco. 2013a. "Narrative Space and Readers' Responses to Stories: A Phenomenological Account.” Style 47 (4): 425-44.

—. 2013b. "Patterns of Cognitive Dissonance in Readers' Engagement with Characters." Enthymema VIII: 21-37.

- 2014. The Experientiality of Narrative: An Enactivist Approach. Berlin: de Gruyter.

- 2016a. Strange Narrators in Contemporary Fiction: Explorations in Readers' Engagement with Characters. Lincoln and London: University of Nebraska Press.

_. 2016b. “"The Bagatelle of Particle Waves': Facing the Hard Problem of Consciousness in Houellebecq's Les Particules élémentaires and Mitchell's Ghostwritten." Critique: Studies in Contemporary Fiction.

Chalmers, David J. 1995. "Facing Up to the Problem of Consciousness." Journal of Consciousness Studies 2 (3): 200-219.

Coetzee, J. M. 1999. The Lives of Animals. Princeton: Princeton University Press. 
Czachesz, István. 2009. "Metamorphosis and Mind: Cognitive Explorations of the Grotesque in Early Christian Literature." In Metamorphoses: Resurrection, Body and Transformative Practices in Early Christianity, edited by Turid Karlsen Seim and Jorunn Økland, 207-30. Berlin and New York: de Gruyter.

Diamond, Cora. 1978. “Eating Meat and Eating People.” Philosophy 53 (206): 465-79.

_. 2003. "The Difficulty of Reality and the Difficulty of Philosophy." Partial Answers 1 (2): $1-26$.

Dillon, Sarah. 2011. “It's a Question of Words, Therefore': Becoming-Animal in Michel Faber's Under the Skin.” Science Fiction Studies 38 (1): 134-54.

Easterlin, Nancy. 2012. A Biocultural Approach to Literary Theory and Interpretation. Baltimore and London: The Johns Hopkins University Press.

Eder, Jens. 2006. "Ways of Being Close to Characters.” Film Studies 8: 68-80.

Faber, Michel. 2000. Under the Skin. Edinburgh: Canongate.

Gonzaga, Violeta. 2014. “Alien's Autobiography.” Amazon.com Customer Reviews: Under the Skin. April 15. http://www.amazon.com/review/R1GUWJ9HF16BWC.

Gymnich, Marion, and Alexandre Segao Costa. 2006. "Of Humans, Pigs, Fish and Apes: The Literary Motif of Human-Animal Metamorphosis and Its Multiple Functions in Contemporary Fiction." L'Esprit Créateur 46 (2): 68-88.

Hakemulder, Frank. 2000. The Moral Laboratory: Experiments Examining the Effects of Reading Literature on Social Perception and Moral Self-Concept. Amsterdam and Philadelphia: John Benjamins.

Keen, Suzanne. 2007. Empathy and the Novel. Oxford and New York: Oxford University Press. Korthals Altes, Liesbeth. 2014. Ethos and Narrative Interpretation: The Negotiation of Values in Narrative Fiction. Lincoln and London: University of Nebraska Press.

Landy, Joshua. 2012. How to Do Things with Fictions. New York: Oxford University Press. 
1b136. 2002. “A Chilly Masterpiece.” Amazon.com Customer Reviews: Under the Skin. June 8. http://www.amazon.com/review/R31FDALNXDDMC2.

Lem, Stanislaw. 1987. “On Stapledon's Star Maker.” Translated by Istvan Csicsery-Ronay Jr. Science Fiction Studies 14 (1): 1-8.

Libby, B. A. 2003. “A Winding Road in the Rain.” Amazon.com Customer Reviews: Under the Skin. April 22. http://www.amazon.com/review/R15QHV786Q8GV2.

Miah, Andy. 2009. “A Critical History of Posthumanism.” In Medical Enhancement and Posthumanity, edited by Bert Gordijn and Ruth Chadwick, 71-94. Dordrecht: Springer.

Mick "Shermanator." 2013. "More than Veggie." Amazon.com Customer Reviews: Under the Skin. December 11. http://www.amazon.com/review/R1F9BCML4KU08L.

Mulhall, Stephen. 2009. The Wounded Animal: J. M. Coetzee and the Difficulty of Reality in Literature and Philosophy. Princeton: Princeton University Press.

Robinson, Katherine Morton. 2001. "Unsolicited Narratives from the Internet: A Rich Source of Qualitative Data." Qualitative Health Research 11 (5): 706-14.

Stableford, Brian M. 2013. "Cosmology." SFE: The Encyclopedia of Science Fiction. http://www.sf-encyclopedia.com/entry/cosmology.

Stoehr. 2003. "Don't Let the Jacket Copy Fool You." Amazon.com Customer Reviews: Under the Skin. January 21. http://www.amazon.com/review/R3PS7HQ1LM3RQI.

Taylor, Matthew A. 2013. Universes Without Us: Posthuman Cosmologies in American Literature. Minneapolis: University of Minnesota Press.

The Guardian Online. 2000. "Flesh Creeping: Review of Under the Skin." 2000. April 1. https://www.theguardian.com/books/2000/apr/01/fiction.reviews2.

Trotter, A. 2005. “Absolutely Right.” Amazon.com Customer Reviews: Under the Skin. May 7. http://www.amazon.com/review/RC78N087E62OL. 
Van Gulick, Robert. 2014. "Consciousness." In The Stanford Encyclopedia of Philosophy, $\begin{array}{llllll}\text { edited by } & \text { Edward } & \text { N. } & \text { Zalta, } & \text { Spring } & \end{array}$ http://plato.stanford.edu/archives/spr2014/entries/consciousness/.

Wolfe, Cary. 2009. "Human, All Too Human: 'Animal Studies' and the Humanities.” PMLA 124 (2): 564-75. 